\title{
15. LATE PLEISTOCENE (BRUNHES) DIATOM RECORD AT SITE 580 ${ }^{1}$
}

\author{
Constance Sancetta, Lamont-Doherty Geological Observatory of Columbia University²
}

\begin{abstract}
The late Quaternary (Brunhes) diatom assemblage at Site 580 is diverse (about 40 species, of which 12 reach abundances $>10 \%$ ) and varies both on the short scale of a single glacial-interglacial cycle and on a longer scale of several hundred thousand years. All of the species show fluctuations in relative abundance which, in many cases, seem to be correlated with glacial-interglacial stages. Superimposed on the basic cyclic record, there is evidence of at least two instances of permanent population readjustment. The early Brunhes was characterized by the presence of true subtropical species, the middle Brunhes by high-amplitude changes in species characteristic of the transition zone, and the late Brunhes by an increase of subarctic species. Since the site itself has not migrated appreciably during this time, the diatom record probably reflects a progressive southward advance of the subarctic gyre at the expense of the subtropical gyre. During the mid-Brunhes, when the Subarctic Front repeatedly crossed the site, the environment was particularly unstable-two radiolarian extinctions (Druppatractus acquilonius and Stylatractus universus), one diatom extinction (Rhizosolenia curvirostris), and the local disappearance of a diatom form (Actinocyclus ochotensis) occurred during this time.
\end{abstract}

\section{INTRODUCTION}

Site 580 is located at $41^{\circ} 37^{\prime} \mathrm{N}, 153^{\circ} 58^{\prime} \mathrm{E}$, about 600 miles east of northern Honshu, in $5375 \mathrm{~m}$ of water. It lies beneath the northern part of the modern Subarctic Front, a transitional zone of temperature and salinity gradients. The site was chosen as the northern end of a latitudinal transect, intended to monitor changes of the front throughout late Neogene time.

A 40-m section representing the Brunhes magnetic interval was recovered by hydraulic piston coring, with excellent recovery ( $91 \%$, see Site 580 chapter, this volume). Both magneto- and biostratigraphic studies indicate a linear sedimentation rate throughout the interval. Samples at roughly $50-\mathrm{cm}$ intervals $(9.2 \mathrm{k} . \mathrm{y}$.) were analyzed for fossil diatoms, to elucidate the history of local oceanographic events and the response of the phytoplankton population to them.

\section{METHODS}

Approximately $1 \mathrm{~g}$ of sediment was disaggregated in $50 \mathrm{ml}$ of a weak solution of $\mathrm{Na}_{4} \mathrm{P}_{2} \mathrm{O}_{7} \cdot 10 \mathrm{H}_{2} \mathrm{O}$ (sodium pyrophosphate) and subjected to $1 \mathrm{~min}$. in an ultrasonic bath. The beaker was then filled to $250 \mathrm{ml}$ with distilled water and the particles allowed to settle for $1 \mathrm{hr}$., after which the supernatant liquid and suspended particles were poured off. The settling procedure, repeated three times, removes most of the clay-sized particles. Slides were prepared by placing an aliquot of the remaining slurry on the slides and drying them on a hot plate. Permount medium and a cover slip were added and the solvent allowed to evaporate.

Diatom population of each sample was analyzed by counting approximately the first 400 specimens encountered in a series of random traverses, at $1250 \times$ magnification. Data are expressed as percent abundance of each taxon relative to the total diatom assemblage.

\footnotetext{
${ }^{1}$ Heath, G. R., Burckle, L. H., et al., Init. Repts. DSDP, 86: Washington (U.S. Govt. Printing Office).

2 Address: Lamont-Doherty Geological Observatory of Columbia University, Palisades, NY 10964.
}

\section{RESULTS}

\section{Cyclic Fluctuations of Thalassiosira trifulta}

When the species abundance data are plotted against depth below surface (Fig. 1), Thalassiosira trifulta Fryxell shows large-amplitude variations which appear to be periodic. A Fourier time-series analysis was done on this record, using the basic age model summarized below.

\begin{tabular}{rr}
\hline $\begin{array}{c}\text { Depth } \\
\text { (m) }\end{array}$ & $\begin{array}{r}\text { Age } \\
\text { (k.y.) }\end{array}$ \\
\hline 0 & 0 \\
8.00 & 125 \\
23.26 & 425 \\
39.60 & 730 \\
\hline
\end{tabular}

The top of Core $1(0 \mathrm{~m})$ is assumed to be modern $(0 \mathrm{k} . \mathrm{y}$.$) .$ This assumption is optimistic; it is likely that deployment of the coring gear disturbed the surface sediments, so that part of the Holocene record was lost. However, the diatom assemblage of the first sample (Sample 580$1-1,15 \mathrm{~cm}$ ) is similar to that of neighboring piston-core tops and very different from that typical of Wisconsinage material (Sancetta, 1979 and unpublished data); thus, no more than 10 k.y. can be missing. Sample 580 $2-4,20 \mathrm{~cm}(8.0 \mathrm{~m})$ was taken to represent the maximum of the last interglacial (Isotope Stage 5e), 125 k.y., based on the coinciding maxima of $T$. oestrupii (Ostenfeld) Proshkina-Lavrenko and Pseudoeunotia doliolus (Wallich) Grunow, two warm-water species. The extinction of the radiolarian Stylatractus universus occurs at $23.26 \mathrm{~m}$ (Morley, this volume); this event was globally synchronous and occurred at 425 k.y. (Morley and Shackleton, $1978)$. The Brunhes/Matuyama boundary $(730$ k.y.) is located at $39.6 \mathrm{~m}$ (Site 580 chapter, this volume). 


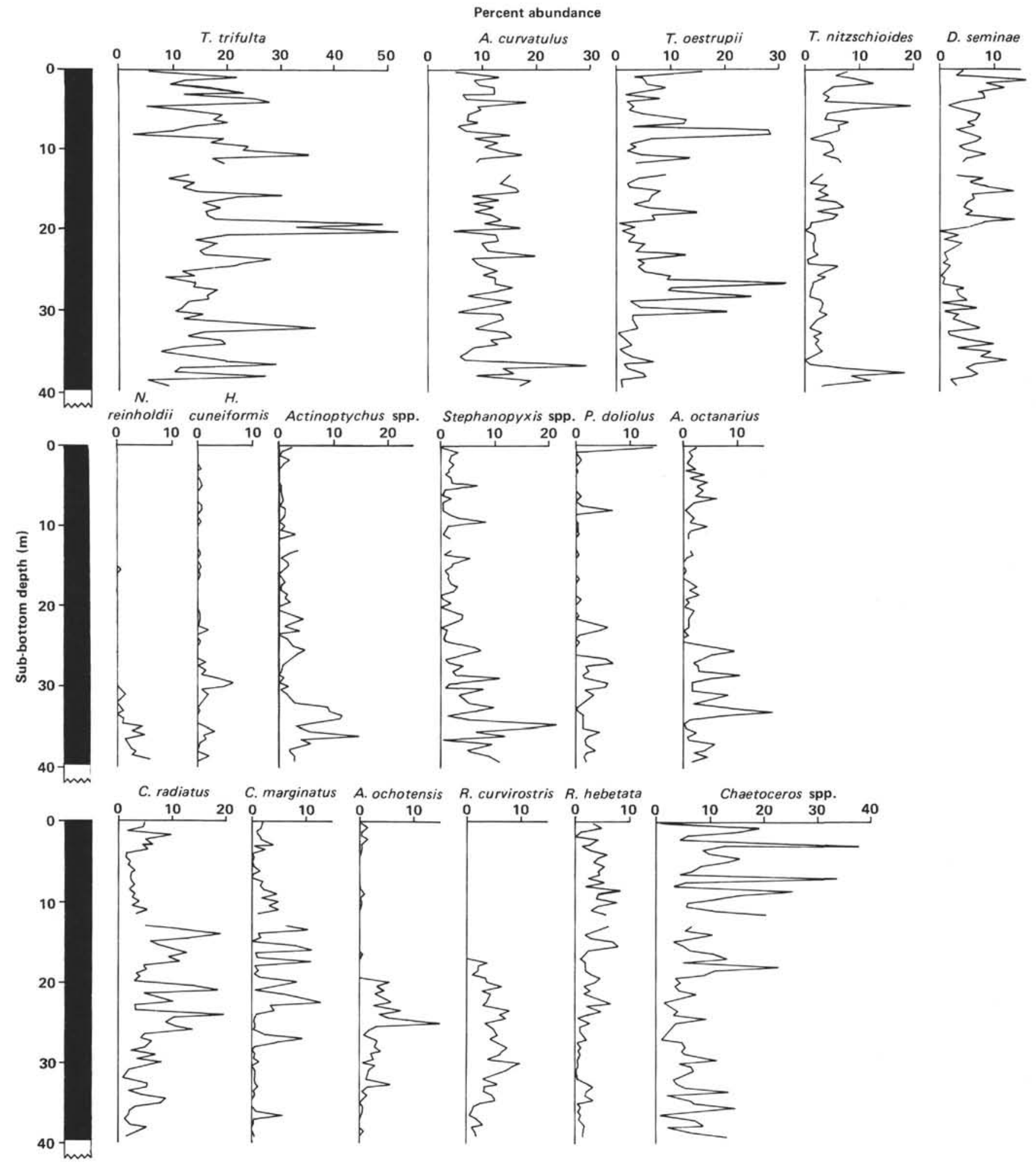

Figure 1. Variation in abundance of diatoms (in percent) at Site 580. Depth scale and paleomagnetic record (from Site 580 chapter, this volume) repeated to the left of each row. The space from 11.5 to $13.0 \mathrm{~m}$ in each curve represents an unrecovered interval.

The results of the Fourier analysis show a strong concentration of variance with a period of 41 k.y. and a weak concentration with a period of 23 k.y. (Fig. 2). These are the periods of axial obliquity and equinoctial precession, respectively, which have been identified in time series of other parameters from marine sediments, including oxygen isotopes in foraminiferal tests (Hays et al., 1976). However, when the abundance of $T$. trifulta is plotted together with the global stacked isotope record of Imbrie et al. (1984), subsampled at 10-k.y. intervals (Fig. 3), it is clear that the species record does not reflect the ice-volume record represented by the isotope values. 


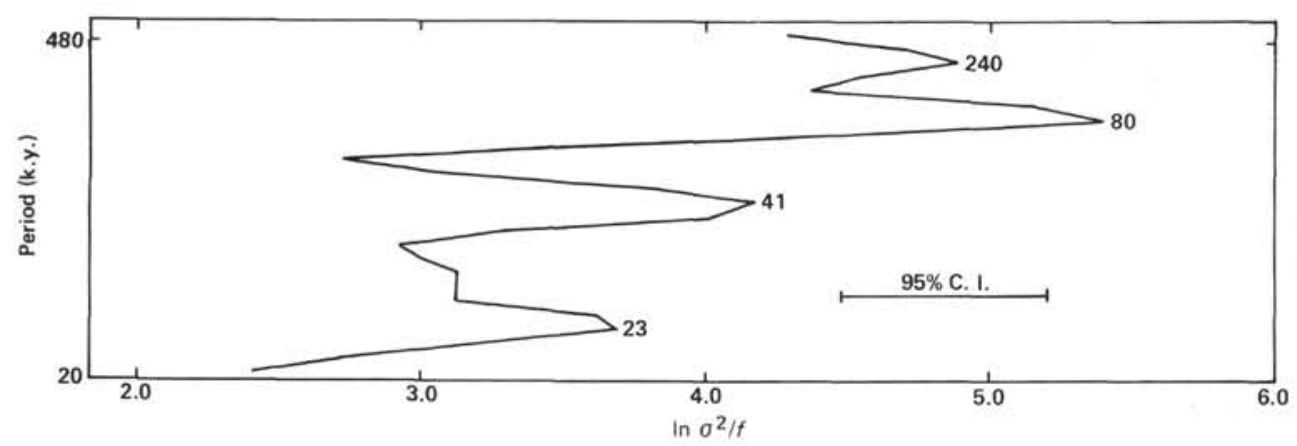

Figure 2. Variance spectrum for $T$. trifulta record. (ln $\sigma^{2} / f=$ natural $\log$ of variance per frequency; C.I. = confidence interval).

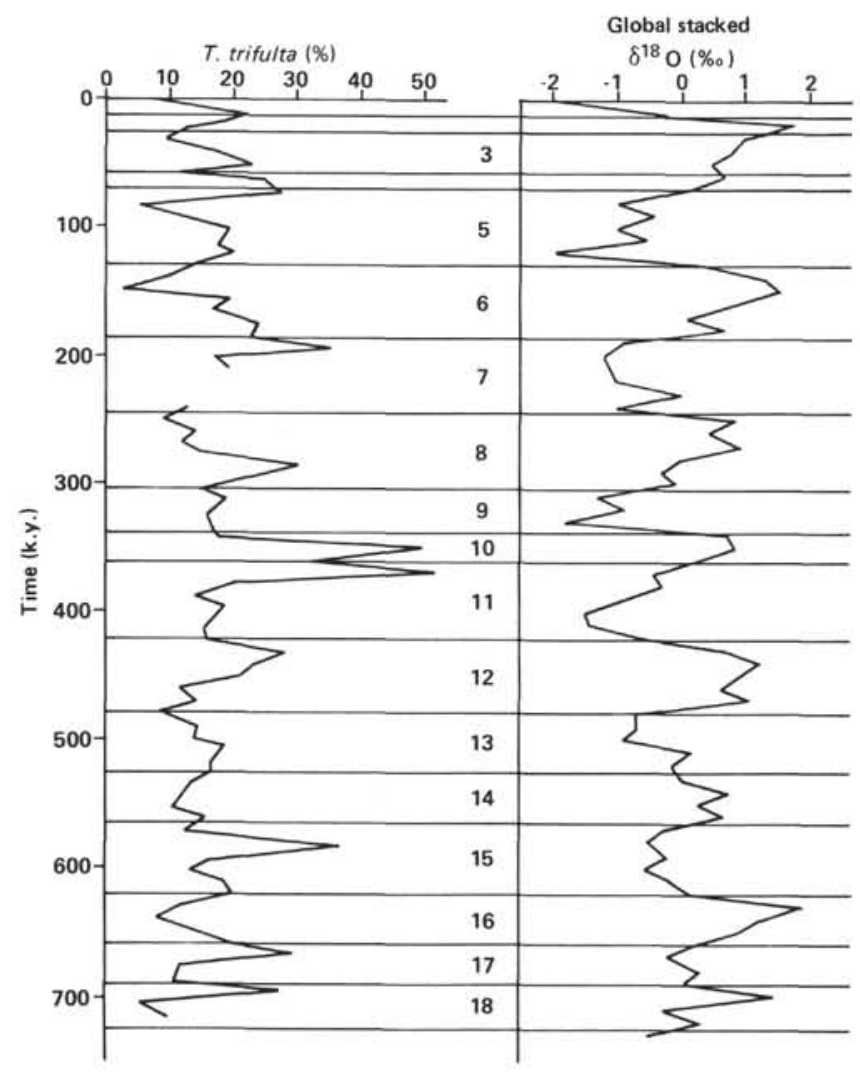

Figure 3. Relative abundance of $T$, trifulta at Site 580 compared with the global stacked isotope record (Imbrie et al., 1984). Age control for the species record is based on the age model used in Fourier analysis, assuming a linear sedimentation rate between points. The isotope record has been subsampled at 10-k.y. intervals (table 7 of Imbrie et al., 1984) to approximate the resolution of the data from Site 580 .

Maxima on the T. trifulta curve usually correspond to slopes on the isotope curve. Thus, maximum abundances of this species occurred during times of transition between glacial and interglacial conditions.

$T$. trifulta occurs in low abundances in modern sediments of the subarctic Pacific, with much higher abundance in the Sea of Okhotsk (Sancetta, 1982b), a region characterized by unusually low-temperature and low-salinity surface waters $\left(7^{\circ} \mathrm{C}, 32.5 \%\right.$ in summer $)$ and a strong thick halocline, bounded at 50 and $150 \mathrm{~m}$ by thermoclines (Yasuoka, 1967, 1968). This vertical structure is the result of prolonged winter sea ice and cold Siberian winds. The high abundances of T. trifulta at Site 580 imply that similar "cold, fresh" conditions existed in the region of the western Subarctic Front during times of climatic transition.

\section{Other Species}

Actinocyclus curvatulus Janisch is also consistently present throughout the Brunhes section (Fig. 1) and shows fluctuations in abundance, although the amplitudes are not as high as for Thalassiosira trifulta. The two records show no overall correlation $(r=-0.03)$, although the largest maxima of $A$. curvatulus do correspond to some of the T. trifulta maxima. A. curvatulus is also common in modern sediments of the Sea of Okhotsk, but is present throughout the subarctic Pacific. The record at Site 580 does not show a clearly interpretable pattern; it may be that this species is rather tolerant of environmental change.

T. oestrupii (Ostenfeld) Proskina-Lavrenko is rare during the Brunhes (averaging 5\%), but shows several intervals of high abundance, at $0.15,6.25-6.50,7.50-8.00$, $11.00,17.50,22.85,26.45,27.95$, and $29.95 \mathrm{~m}$, corresponding to Isotope Stages $1,5,7,9,11,13$, and 14 . This suggests that $T$. oestrupii represents warmer, more saline waters typical of the modern interglacial values in the region $\left(15^{\circ} \mathrm{C}, 33.5 \%\right.$ in summer). Sancetta (1979) found that $T$. oestrupii is characteristic of the assemblage underlying the Subarctic Front in the North Pacific $\left(42-45^{\circ} \mathrm{N}\right)$, the transition zone from the cold low-salinity subarctic gyre to the warm saline subtropical gyre. $T$. oestrupii was excluded from the westernmost part of the transition zone during the last glacial maximum and existed only in the central North Pacific (Sancetta, 1979), suggesting that it does not tolerate the extreme temperature and salinity seasonal fluctuations of the western region. Its occasional high abundance at Site 580 may represent interglacial periods in which the effect of subarctic water was particularly low.

Thalassionema nitzschioides (Grunow) $\mathrm{H}$. and $\mathrm{M}$. Peragallo also averages $<5 \%$ through most of the section, but has maxima at $1.75,4.50$, and $37.20 \mathrm{~m}$, corresponding to Isotope Stages 3, late 5, and 17. The late Stage 5 maximum is associated with the occurrence of rare freshwater diatoms (Stephanodiscus spp.) and opaline phytoliths. T. nitzschioides is a cosmopolitan spe- 
cies, often common in areas of high productivity, such as the eastern equatorial Pacific (Hasle and de Mendiola, 1967; L. Burckle, pers. comm., 1982). The three maxima at Site 580 may represent times of increased wind stress and upwelling within the transition zone.

The record of Denticulopsis seminae (Simonsen and Kanaya) Simonsen does show a trend, but the significance is not clear. During the early part of the Brunhes (Stage 18 to late 13 ), D. seminae averages $5 \%$ of the flora. Following this is a prolonged minimum (late Stage 13 to late Stage 11) and then a return to an average of $5 \%$ (late Stage 11 through Stage 1) with maxima at 1.22, 14.9 , and $18.5 \mathrm{~m}$ (Stages 2,8 , and 10 ). D. seminae today is characteristic of the entire subarctic gyre, particularly the eastern and central part, where surface temperature and salinity are intermediate $\left(9-12^{\circ} \mathrm{C}, 32.5-32.75 \%\right.$ in summer). Site 580 lies outside this biogeographic region (being to the south and west), so that conditions at the site may be presumed to be marginal for the species. The three maxima may represent brief expansions of eastern-subarctic conditions during times of peak glacial advance on land.

A group of species shows markedly higher average abundance during the early Brunhes. These include Nitzschia reinholdii Kanaya and Koizumi, Hemidiscus cuneiformis Wallich, Actinoptychus spp. (A. senarius Ehrenberg and $A$. vulgaris Schumann), Stephanopyxis spp., Pseudoeunotia doliolus (Wallich) Grunow, and, over a shorter interval, Actinocyclus octonarius Ehrenberg. With the exception of Stephanopyxis spp., these forms are all typical of warm, saline tropical and subtropical waters today. The distribution of Stephanopyxis in sediments has not been defined, but personal observations suggest that it is more common along temperate continental margins. The consistent (albeit fluctuating) presence of these species during the early Brunhes, and their virtual absence from the later part of the record, suggest that conditions at Site 580 were generally more "subtropical" during Stages 18-12 than they have been since. The extinction of $N$. reinholdii occurs within this interval, at 550 k.y. (early Stage 14). Barron (1980) estimated an age of 630 k.y. for this event, which corresponds to the small acme ending at $34 \mathrm{~m}$ (Stage 16). The event may be time transgressive (Sancetta, 1982a), or Barron may have overlooked the very rare occurrence of the species just prior to its disappearance.

Two species, Coscinodiscus radiatus Ehrenberg and C. marginatus Ehrenberg, show low values in the early and late Brunhes, and high-amplitude fluctuations during the middle Brunhes (13-28 m, Stages 8-13). Neither species shows consistent maxima or minima corresponding to isotopic stages. C. marginatus is more common today in the southern part of the subarctic gyre just north of the Subarctic Front, whereas $C$. radiatus occurs within the transition zone. The high-amplitude fluctuations of these two species suggest an interval of instability in the front, which repeatedly migrated across the site during the mid-Brunhes.

The record of two other species shows that the midBrunhes was a time of instability and of a changing (stressful) environment. A. ochotensis Jousé, which was a minor member of the floral assemblage during the early Brunhes, increased in average abundance during the middle Brunhes and then disappeared from the region. Subsequently, Rhizosolenia curvirostris Jousé suffered extinction during Stage 8 (276 k.y., Morley et al., 1982).

Following the extinction of $R$. curvirostris, a congeneric species, $R$. hebetata Bailey, increased in average abundance and remained consistently more common through the late Brunhes (Stages 8-1). Today this species is limited to the subarctic gyre and does not occur in sediments at or south of the Subarctic Front. The increased occurrence of $R$. hebetata during the late Brunhes suggests that the influence of subarctic waters became more important during that time.

Finally, spores of the genus Chaetoceros fluctuate in abundance throughout the Brunhes, with an overall increase in amplitude in the late Brunhes (Stages 7-1). The highest maxima occur at $0.75,3.08,7.00,8.50,11.50$, and $18.00 \mathrm{~m}$, corresponding to Isotope Stages $1 / 2,3 / 4$, 6,7 , and $9 / 10$. Chaetoceros species are characteristic of high productivity along continental margins today; in the North Pacific they are dominant in sediments underlying the East Kamchatka and Oyashio Currents, regions of maximum productivity in cold, low salinity surface waters. The high-amplitude fluctuations at Site 580 during the late Brunhes suggest short periods of increased input from the productive Oyashio Current, particularly during times of climatic transition.

\section{TAXONOMIC NOTES}

Most of the species discussed here have been described and illustrated by numerous workers, and there seems to be little taxonomic confusion in the literature. A review of systematics in this chapter is therefore unnecessary. I have discussed taxonomic identification of subarctic species elsewhere (Sancetta, 1982b); I note here only a few cases that may require clarification.

Actinocyclus octonarius is synonymous with $A$. ehrenbergii Ralfs. The latter epithet is illegitimate, being a junior synonym.

Actinocyclus ochotensis is probably not a true species, but an irregular morphotype of $A$. curvatulus. A complete intergradation can be seen in these forms. Further work is needed to resolve the question.

\section{ACKNOWLEDGMENTS}

I am grateful to the technical and scientific staff of Leg 86 for making the samples available for study. The chapter was reviewed by Lloyd Burckle and Joseph Morley, who freely shared their own results from Leg 86, and by John Barron and Nicklas Pisias, who provided helpful criticism. Research was supported by NSF Grant OCE81-09933. This is Lamont-Doherty Contribution No. 3722.

\section{REFERENCES}

Barron, J. A., 1980. Lower Miocene to Quaternary diatom biostratigraphy of Leg 57, off northeastern Japan, Deep Sea Drilling Project. In Scientific Party, Init. Repts. DSDP, 56, 57, Pt. 2, (U.S. Govt. Printing Office), 641-685.

Hasle, G. R., and de Mendiola, B. R. E., 1967. The fine structure of some Thalassionema and Thalassiothrix species. Phycologia, 6: 107-125.

Hays, J. D., Imbrie, J., and Shackleton, N. J., 1976. Variations in the Earth's orbit: pacemaker of the ice ages. Science, 194:1121-1132. 
Imbrie, J., Hays, J. D., Martinson, D. G., McIntyre, A., Mix, A. C., Morley, J. J., Pisias, N. G., Prell, W. L., and Shackleton, N. J., 1984. The orbital theory of Pleistocene climate: support from a revised chronology of the marine $\delta^{18} \mathrm{O}$ record. In Berger, A., et al. (Eds.), Milankovich and Climate: Dordrecht (D. Riedel), pp. 269-305.

Morley, J. J., Hays, J. D., and Robertson, J. H., 1982. Stratigraphic framework for the late Pleistocene in the northwest Pacific Ocean. Deep-Sea Res., 29:1485-1499.

Morley, J. J., and Shackleton, N. J., 1978. Extension of the radiolarian Stylatractus universus as a biostratigraphic datum to the Atlantic Ocean. Geology, 7:309-311.

Sancetta, C., 1979. Oceanography of the North Pacific during the last 18,000 years: Evidence from fossil diatoms. Mar. Micropaleontol., $4: 103-123$. 1982a. Diatom biostratigraphy and paleoceanography, Deep Sea Drilling Project Leg 68. In Prell, W. L., Gardner, J. V., et al., Init. Repts. DSDP, 68: Washington (U.S. Govt. Printing Office), 301-309.

1982b. Distribution of diatom species in surface sediments of the Bering and Okhotsk seas. Micropaleontology, 28:221-257. Yasuoka, T., 1967. Hydrography in the Okhotsk Sea (1). Oceanogr., 19:61-72. $55-63$.

, 1968. Hydrography in the Okhotsk Sea (2). Oceanogr., 20:

Date of Initial Receipt: 28 October 1984

Date of Acceptance: 11 May 1984 